\title{
Pengaruh Terpaan Adegan Kekerasan dalam Game Online Terhadap Sikap Agresifitas Remaja
}

\author{
Puput Yunita Dewi \\ Program Studi Ilmu Komunikasi Fakultas Ilmu Sosial Dan Ilmu Politik \\ Universitas Pembangunan Nasional"Veteran" Yogyakarta \\ Jl. Babarsari No. 2 Tambakbayan Yogyakarta 55282, Telp. (0274) 485268
}

\begin{abstract}
Online gaming comes as a form of technological development that is increasingly sophisticated. Online games are becoming a trend and are in demand because of the much entertainment on offer. The types of online games are very diverse and have their own uniqueness. Some games have an aggressive nature that shows violent scenes. Teenagers as a part of society who tend to be close to the game, along with the process of selfsearching, are prone to contracting the aggressive attitudes displayed in online games. The purpose of this study is to find out how online gaming affects the level of adolescent aggressiveness. The selected research method is quantitative based on numbers and calculations. Sampling is done using surveys. The sampling point is Game Center "Monster" in Seturan, Depok, Sleman. The results of this study were that the majority of adolescents as respondents had high scores of violent scenes in online games. Most respondents were in high aggressive categorization. Based on the calculation results with product moment correlation analysis, the relationship between violent scenes in online games and adolescent aggressiveness was $88.9 \%$. That is, the correlation is positive or direct, so the increasingly frequent use of online games then the level of youth aggressiveness will be high. Variable scenes of violence in online games also have a positive influence. This means that the higher the violent scenes in online games, the higher the rate of adolescent aggressiveness. Keywords: online games, aggressiveness rate, adolescents
\end{abstract}

\begin{abstract}
Abstrak
Game online hadir sebagai bentuk perkembangan teknologi yang semakin canggih. Game online menjadi tren dan banyak diminati karena banyak hiburan yang ditawarkan. Jenis game online sangat beragam dan memiliki keunikannya masing-masing. Beberapa permainan memiliki sifat agresif dimana menunjukkan adegan-adegan kekerasan. Remaja sebagai lapisan masyarakat yang cenderung dekat dengan game, bersamaan dengan proses pencarian jati diri, rawan tertular sikap agresif yang ditampilkan di game online. Tujuan penelitian ini adalah mengetahui bagaimana pengaruh game online terhadap tingkat agresifitas remaja. Metode penelitian yang dipilih ada kuantitatif yang didasarkan pada angka dan perhitungan. Pengambilan sampel dilakukan menggunakan survey. Tempat pengambilan sampel adalah Game Center "Monster" di Seturan, Depok, Sleman. Hasil penelitian ini adalah sebagian besar remaja sebagai responden memiliki skor adegan kekerasan dalam game online tinggi. Sebagian besar responden masuk dalam kategorisasi agresifitas tinggi. Berdasarkan hasil perhitungan dengan analisis korelasi product moment, hubungan antara adegan kekerasan dalam game online dengan agresifitas remaja sebesar 88,9\%. Artinya, korelasinya positif atau searah, sehingga penggunaan game online yang semakin sering maka tingkat agresifitas remaja akan tinggi. Variabel adegan kekerasan dalam game online juga mempunyai pengaruh positif. Artinya semakin tinggi adegan kekerasan dalam game online, semakin tinggi pula tingkat keagresifan remaja.

Kata kunci: game online, tingkat agresifitas, remaja
\end{abstract}

\section{Pendahuluan}

Dunia saat ini tengah dilanda perkembangan dan kemajuan pesat dalam bidang ilmu pengetahuan dan teknologi. Bidang ini paling banyak menarik perhatian, karena yang ditunjukan sangat nyata pengaruhnya pada kehidupan manusia yang terus berkembang sejalan dengan tantangan jaman. Perkembangan ilmu pengetahuan diakui telah banyak memberikan jasa yang sangat besar kepada umat manusia dalam bentuk sumbangansumbangan berupa kemajuan teknologi. Perkembangan ilmu dan teknologi yang semakin pesat ternyata membawa perubahan dalam segala lapisan kehidupan. Kreativitas manusia semakin berkembang sehingga 
mendorong diperolehnya temuan-temuan baru dalam teknologi yang dapat dimanfaatkan sebagai sarana peningkatan kesejahteraan umat manusia. Salah satu produk manusia tersebut adalah internet, teknologi internet dewasa ini semakin berkembang pesat, salah satu manfaatnya adalah sebagai sarana hiburan, misalnya untuk bermain. Permainan video game dengan menggunakan koneksi internet tersebut dikenal sebagai game online.

Menurut Severin (dalam Giandi, Mustikasari E, \& Suprapto A, 2012), game online adalah sebuah fasilitas penyedia jasa hiburan berbentuk permainan yang dapat diakses secara daring menggunakan koneksi internet. Tiap pemain dapat berkomunikasi secara langsung dan terhubunga satu sama lain. Sebagai media game online sangat berpengaruh terhadap pikiran manusia, yang diserap melalui dua panca indera yakni melihat dan mendengar.

Game online menjadi tren baru yang banyak diminati karena seseorang tidak lagi bermain sendirian, tetapi memungkinkan bermain bersama puluhan orang sekaligus dari berbagai lokasi. Seiring dengan pesatnya perkembangan teknologi internet, game online juga mengalami perkembangan yang pesat. Terlihat dari munculnyaberbagaijenispermainanonline seperti Ragnarok Online, Risk Your Life, dan GunBond.

Perkembangan game komputer dan video game yang kian memanjakan para pemainnya dengan teknologi-teknologi mutakhir merupakan fenomena menarik untuk dicermati. Meski sejarah video game dan game komputer mencakup rentang waktu sekitar lima dekade, keduanya meraih popularitas sebagai bagian dari peradaban manusia modern di akhir tahun 1970 (Mursalini, 2007) Sebuah bisnis, perhitungan tersebut memang menggambarkan prospek yang menguntungkan. Semakin banyak peminat game online, semakin tinggi persaingan antara produsen game online. Mereka semakin gencar membuat jenis game online baru untuk mendapatkan lebih banyak peminat.
Fenomena maraknya game online juga bisa dilihat dari majalah dan buku panduan untuk bermaingame. Isinya selainmengulas game-game keluaran terbaru, juga memberi metode "curang" bagi para gamer. Selain itu tidak jarang digelar kompetisiantargamerpada sejumlah gamecenter.

Di kota-kota besar di Indonesia terutama di pusat-pusat perbelanjaan, sering kita jumpai pergelaran game online yang menawarkan berbagai macam jenis permainan dan dipenuhi oleh remaja, kota-kota besar tersebut diantaranya adalah Yogyakarta. Tidak sedikit pula game center yang terdapat di kota Pendidikan ini, hanya dengan membayar relatif murah sebesar Rp. 3.000 per jamnya mereka betah menghabiskan waktu berjam-jam terlibat dalam kesenangan game online. Untuk itu penelitian ini akan dilaksanakan di kota Yogyakarta.

Lebih lanjut hasil dari penelitian Jansz menyatakan bahwa gamers kebanyakan adalah remaja laki-laki. Kaum remaja ini menemukan game online sebagai tempat eksperimen mereka melepas berbagai emosi. Hal ini sejalan dengan Bakker yang menyatakan bahwa para pecandu game rata-rata antara 13-30 tahun dengan prosentase 80 persen berusia 13-25 tahun (http://www.anneahira.com/pengaruhgame-online-terhadap-prestasbelajar.htm).

Mereka dapat dikatakan sebagai pecandu jika mereka sampai mengabaikan kehidupan sehari-hari, seperti sekolah, bekerja, bergaul, kebersihan, dan kesehatan pribadi.

Periode remaja adalah periode pemantapan identitas diri. Pengertiannya akan "siapa aku" yang dipengaruhi oleh pandangan orang-orang sekitarnya serta pengalaman-pengalaman pribadinya akan menentukan pola perilakunya sebagai orang dewasa. Pemantapan identitas diri tidak selalu mulus, tetapi sering melalui proses yang panjang dan bergejolak. Oleh karena itu, banyak ahli menamakan periode ini sebagai masa-masa stress (http://www.ketok.com/).

Hal yang mengkhawatirkan, jika remaja yang pada umumnya masih duduk di bangku sekolah menghabiskan waktu dengan main 
game online dapat menyebabkan merosotnya prestasi belajar. Begitu juga remaja dapat tidak mempunyai kemampuan untuk bersosialisasi dengan baik dalam lingkungan keluarga maupun lingkungan pergaulannya di masyarakat. Lebih berbahaya lagi, pengaruh dari game online dapat menyebabkan meningkatnya agresivitas. Ini dapat saja terjadi karena pengaruh permainan yang menampilkan perilaku agresif.

Seperti permainan yang menampilkan perkelahian brutal, berdarah-darah, sadis, adegan penyiksaan, pembunuhan dan lain-lain. Jenis permainan yang digemari tersebut dan dinikmati secara berulang-ulang, maka secara tanpa sadar dan berangsur-angsur perilaku agresif tersebut akan terekam dalam memori alam bawah sadar remaja. Akibatnya, remaja menjadi terbiasa menyaksikan adegan kekerasan, sehingga sikap agresif pada remaja begitu mudah terbentuk.

Masa remaja merupakan masa dimana pencarian jati diri, dengan kata lain, remaja mencari model-model yang dapat ditiru ke dalam perilakunya. Banyak cara yang dilakukan oleh remaja untuk mendapatkan model-model tersebut, salah satunya dengan melihat modelmodel yang ada di game online. Sementara itu, permainan-permainan game online banyak yang bertemakan kekerasan, seperti memukul, menendang, dan menembak lawan.

Pengamatan atau observasi terhadap tingkah laku sebuah model akan membentuk tingkah laku pada sang pengamat. Perilaku agresif yang dilakukan oleh model juga akan membentuk agresivitas pada sang pengamat. Dengan demikian dapat dikatakan bahwa bermain game online jenis agresif mempunyai hubungan yang positif dengan agresivitas pada pemainnya.

Remaja yang mempunyai tingkah laku seperti diatas, merupakan tingkah laku yang bermasalah. Tingkah laku yang bermasalah mencakup berbagai macam tingkah laku yang sangat banyak ciri-ciri. Tingkah laku itu juga berbeda dalam akibat yang ditimbulkan pada lingkungan. Namun remaja tersebut mudah menjadi ejekan teman-temannya dan cenderung menjadi agresif. Sedangkan perilaku agresif tadi merupakan tanda-tanda kuat akan tingkah laku kenakalan remaja dikemudian hari. Pada dasarnya, tidak semua jenis game online dapat berdampak pada agresivitas. Bahwasanya game online terbagi menjadi dua kelompok, yakni game online jenis agresif dan non agresif. Game online jenis agresif misalkan pada Arcade Games. Pada permainan Arcade mudah dimengerti, menyenangkan dan grafiknya bagus walau biasanya sederhana. Pengertian mudah dimengerti dan menyenangkan dikarenakan permainan ini hanyalah berkisar pada hal-hal yang disenangi oleh para pecinta game online seperti pukulmemukul, tembak-menembak, tusuk-menusuk, kejar-mengejar dan semua yang mudah serta menyenangkan. Sedangkan game online jenis non agresif seperti Fun games, Strategic Games, Adventure Games, dan Simulation Games.

Berdasarkan game online jenis non agresif, karena jenis permainan yang hanya bersifat "mengolah" otak saja dan tidak mengandung unsur kekerasan, maka dapat diasumsikan tidak akan muncul agresivitas. Kemungkinan adanya perbedaan mekanisme pertahanan diri remaja yang bermain game online jenis agresif dan non agresif serta bagaimana macam situasi kondisi lingkungan budaya yang memiliki ciri khas tertentu menjadi suatu fenomena yang menarik, disamping itu maraknya agresivitas akhirakhir ini yang dilakukan kelompok remaja kota merupakan sebuah kajian yang menarik pula untuk dibahas. Agresivitas pada remaja yang pada umumnya sangat merugikan dan perlu upaya untuk mencari jalan keluar dari masalah ini atau setidaknya mengurangi. Perkembangan teknologi yang terpusat pada kota-kota besar mempunyai korelasi yang erat dengan meningkatnya agresivitas yang dilakukan oleh remaja.

Kekerasan merupakan tindakan agresif dan pelanggaran (penyiksaan, pemukulan, pemerkosaan, dan lain-lain) yang menyebabkan 
atau dimaksudkan untuk menyebabkan penderitaan atau menyakiti orang lain, dan hingga batas tertentu tindakan menyakiti binatang dapat dianggap sebagai kekerasan, tergantung pada situasi dan nilai-nilai sosial yang terkait dengan kekejaman terhadap binatang. Istilah "kekerasan" juga mengandung kecenderungan agresif untuk melakukan perilaku yang merusak. Kerusakan harta benda biasanya dianggap masalah kecil dibandingkan dengan kekerasan terhadap orang.

Kekerasan pada dasarnya tergolong ke dalam dua bentuk - kekerasan sembarang, yang mencakup kekerasan dalam skala kecil atau yang tidak terencanakan, dan kekerasan yang terkoordinir, yang dilakukan oleh kelompokkelompok baik yang diberi hak maupun tidak - seperti yang terjadi dalam perang (yakni kekerasan antar-masyarakat) dan terorisme. Perilaku kekerasan semakin hari semakin nampak, dan sungguh sangat mengganggu ketentraman hidup. Jika hal ini dibiarkan, tidak ada upaya sistematik untuk mencegahnya, tidak mustahil kita sebagai bangsa akan menderita rugi oleh karena kekerasan tersebut. Remaja akan menuai akibat buruk dari maraknya perilaku kekerasan di masyarakat baik dilihat dari kacamata nasional maupun internasional. Agresif menurut Baron (dalam Koeswara,1988:05) adalah tingkah laku yang ditunjukkan untuk melukai dan mencelakakan individu lain ang tidak menginginkan datangnya tingkah laku tersebut. Definisi ini mencangkup empat hal yaitu tingkah laku, tujuan untuk melukai (termasuk mematikan atau membunuh), individu yang menjadi pelaku dan individu yang menjadi korban, dan ketidak inginan si korban menerima tingkah laku si pelaku.

Agresif dapat dilakukan tanpa tujuan menyakiti, bisanya dalam bentuk keinginan untuk mempunyai pengaruh atau kekuasaan atas orang lain, atau untuk mendapatkan citra diri yang baik. Sedangkan beberapa serangan yang merupakan usaha melakukan pksaan hingga merugikan orang lain apapun bentuknya adalah termasuk agresif yang sifatnya menyakiti.
Remaja dalam arti adolescence (inggris) berasal dari kata latin adolencere yang artinya tumbuh kearah kematangan. Kematangan disini tidak berarti kematangan fisik, tetapi juga kematangan sosial psikologi (Sarwono, 2003:8).

Lazimnya masa remaja dianggap mulai pada saat anak secara seksual menjadi matang dan berakhir saat ia mencapai usia matang, matang secara hukum. Namun, penelitian tentang perubahan perilaku, sikap dan nilainilai sepanjang masa remaja tidak hanya menunjukkan bahwa setiap perubahan terjadi lebih cepat pada awal masa remaja dan pada tahap akhir masa remaja, tetapi juga menunjukkan bahwa perilaku, sikap dan nilainilai pada awal masa remaja berbeda dengan pada akhir masa remaja (Hurlock, 1980:206).

\section{Metode Penelitian}

Penelitian ini menggunakan metode kuantitatif karena analisisnya didasarkan pada angka dan perhitungan. Sehingga hasil yang diperoleh akan dipergunakan sebagai kesimpulan. Disamping itu data ini dapat digunakan untuk menguji hipotesis guna mengetahui perbedaan, perbandingan dan tingkat pengaruh.

Penelitian ini menggunakan jenis penelitian survey, yaitu penelitian yang mengambil sampel dari satu populasi dan menggunakan kuesioner sebagai alat pengumpulan data yang pokok. Kelebihan dan kekurangan kuesioner adalah responden dapat memikirkan berbagai pertanyaan yang ditanyakan pada dirinya. Kemungkinan ada waktu diskusi dengan orang lain sehingga setiap jawaban yang salah dapat dengan mudah diperbaiki oleh responden tersebut.

Disamping itu metode penelitian survey meneliti hubungan antara dua variabel, meramalkanvariabeltidakbebas daripengetahuan tentang variabel bebas dan meratakan jalan untuk membuat rancangan penelitian eksperimental.

Penelitian ini bertujuan untuk meneliti sejauh mana pengaruh terpaan adegan kekerasan dalam game online terhadap sikap agresifitas pada remaja. 
Mengingat jumlah pelanggan game online dan data pelanggan game online khususnya di Daerah Istimewa Yogyakarta begitu besar dan tidak tercatat maka peneliti membatasi pelaksanaan penelelitian ini hanya dilakukan di salah satu game net (game canter) yang ada di kota Yogyakarta. Adapun lokasi penelitian yang diambil oleh peneliti adalah Game Center Monster, J1. Seturan, Depok Sleman, Yogyakarta. Dengan alasan Yogyakarta sebagai kota pelajar yang sebagian besar penduduknya adalah pelajar yang berkaitan erat dengan dunia pendidikan, selain itu perkembangan teknologi informasi (internet) sebagai wacana keilmuwan yang mudah diperoleh. Pemilihan Game Center "Monster" didasarkan pada pertimbangan, kecepatan akses dengan system jaringan wavelan sehingga banyak pengunjung yang memilih Game Center tersebut, sehingga kondisi ini memungkinkan diperolehnya data yang maksimal dan efektif.

Subjek penelitian adalah remaja yang dipilih secara rutin bermain game online minimal $3 \mathrm{x}$ perminggu. Dengan asumsi digolongkan menjadi pengakses geme online pasif serta remaja yang dipilih secara rutin lebih dari $3 x$ perminggu digolongkan pengakses game online aktif.

\section{Hasil Penelitian Dan Pembahasan}

Dunia saat ini tengah dilanda perkembangan dan kemajuan pesat dalam bidang ilmu pengetahuan dan teknologi. Bidang ini paling banyak menarik perhatian, karena yang ditunjukan sangat nyata pengaruhnya pada kehidupan manusia yang terus berkembang sejalan dengan tantangan jaman. Perkembangan ilmu pengetahuan diakui telah banyak memberikan jasa yang sangat besar kepada umat manusia dalam bentuk sumbangansumbangan berupa kemajuan teknologi.

Perkembangan ilmu dan teknologi yang semakin pesat ternyata membawa perubahan dalam segala lapisan kehidupan. Kreativitas manusia semakin berkembang sehingga mendorong diperolehnya temuan-temuan baru dalam teknologi yang dapat dimanfaatkan sebagai sarana peningkatan kesejahteraan umat manusia. Salah satu produk manusia tersebut adalah internet, teknologi internet dewasa ini semakin berkembang pesat, salah satu manfaatnya adalah sebagai sarana hiburan, misalnya untuk bermain. Permainan video game dengan menggunakan koneksi internet tersebut dikenal sebagai game online. Sebagai media game online sangat berpengaruh terhadap pikiran manusia, yang diserap melalui dua panca indera yakni melihat dan mendengar.

Hal yang mengkhawatirkan, jika remaja yang pada umumnya masih duduk di bangku sekolah menghabiskan waktu dengan main game online dapat menyebabkan merosotnya prestasi belajar. Begitu juga remaja dapat tidak mempunyai kemampuan untuk bersosialisasi dengan baik dalam lingkungan keluarga maupun lingkungan pergaulannya di masyarakat. Lebih berbahaya lagi, pengaruh dari game online dapat menyebabkan meningkatnya agresivitas. Ini dapat saja terjadi karena pengaruh permainan yang menampilkan perilaku agresif.
Agresif
menurut
Baron
(dalam

Koeswara,1988:05) adalah tingkah laku yang ditunjukkan untuk melukai dan mencelakakan individu lain ang tidak menginginkan datangnya tingkah laku tersebut. Faktor penyebab remaja berperilaku agresif bermacam-macam, sehingga dapat dikelompokkan menjadi faktor sosial, faktor lingkungan, faktor situasional, faktor hormon, alkohol, obat-obatan (faktor yang berasal dari luar individu) dan sifat kepribadian (faktor-faktor yang berasal dari individu).

Permainan yang menampilkan perkelahian brutal, berdarah-darah, sadis, adegan penyiksaan, pembunuhan dan lain-lain. Jenis permainan yang digemari tersebut dan dinikmati secara berulang-ulang, maka secara tanpa sadar dan berangsur-angsur perilaku agresif tersebut akan terekam dalam memori alam bawah sadar remaja. Akibatnya, remaja menjadi terbiasa menyaksikan adegan kekerasan, sehingga sikap agresif pada remaja begitu mudah terbentuk. 
Masa remaja merupakan masa dimana pencarian jati diri, dengan kata lain, remaja mencari model-model yang dapat ditiru ke dalam perilakunya. Banyak cara yang dilakukan oleh remaja untuk mendapatkan model-model tersebut, salah satunya dengan melihat modelmodel yang ada di game online. Sementara itu, permainan-permainan game online banyak yang bertemakan kekerasan, seperti memukul, menendang, dan menembak lawan.

Bandura (Koeswara, 1988:05) menyatakan bahwa pengamatan atau observasi terhadap tingkah laku sebuah model akan membentuk tingkah laku pada sang pengamat. Perilaku agresif yang dilakukan oleh model juga akan membentuk agresivitas pada sang pengamat. Dengan demikian dapat dikatakan bahwa bermain game online jenis agresif mempunyai hubungan yang positif dengan agresivitas pada pemainnya.

Remaja yang mempunyai tingkah laku seperti diatas, merupakan tingkah laku yang bermasalah. Tingkah laku yang bermasalah mencakup berbagai macam tingkah laku yang sangat banyak ciri-ciri. Tingkah laku itu juga berbeda dalam akibat yang ditimbulkan pada lingkungan. Namun remaja tersebut mudah menjadi ejekan teman-temannya dan cenderung menjadi agresif. Sedangkan perilaku agresif tadi merupakan tanda-tanda kuat akan tingkah laku atau kenakalan remaja dikemudian hari.

Game online jenis agresif misalkan pada Arcade Games. Pada permainan Arcade mudah dimengerti, menyenangkan dan grafiknya bagus walau biasanya sederhana. Pengertian mudah dimengerti dan menyenangkan dikarenakan permainan ini hanyalah berkisarpada hal-halyang disenangi umum seperti pukul-memukul, tembakmenembak, tusuk-menusuk, kejar-mengejar dan semua yang mudah serta menyenangkan.

Mekanisme pertahanan diri remaja yang bermain game online jenis agresif serta bagaimana macam situasi kondisi lingkungan budaya yang memiliki ciri khas tertentu menjadi suatu fenomena yang menarik, disamping itu maraknya agresivitas akhir-akhir ini yang dilakukan kelompok remaja kota merupakan sebuah kajian yang menarik. Agresivitas pada remaja yang pada umumnya sangat merugikan dan perlu upaya untuk mencari jalan keluar dari masalah ini atau setidaknya mengurangi.

Perkembangan teknologi yang terpusat pada kota-kota besar mempunyai korelasi yang erat dengan meningkatnya agresivitas yang dilakukan oleh remaja. Penggunaan Game online yang berlebihan mampu mempengaruhi agresifitas remaja, yaitu dapat menciptakan perubahan-perubahan dalam diri seorang termasuk perubahan sikap pada remaja.

Sikap adalah keadaan mental dan saraf dari kesiapan, yang diatur melalui pengalaman yang memberikan pengaruh dinamik atau terarah terhadap respons individu pada semua objek dan situasi yang berkaitan dengannya (G.W. Allport, 1935:810). Sikap mengandung tiga komponen yang membentuk struktur sikap yaitu: Komponen Kognitif (komponen perseptual), yaitu komponen yang berkaitan dengan pengetahuan, pandangan, keyakinan, yaitu halhal yang behubungan dengan bagaimana orang mempersepsi terhadap objek sikap. Melalui game online remaja memiliki pengetahuan bagaimana cara untuk menakhlukkan lawan, karena remaja melihat adegan-adegan kekerasan dalam game online seperti memukul, menendang bahkan menembak. Remaja yang di usia nya masih sangat labil sangat mudah menerima dan menyerap apa yang dia lihat. Komponen afektif (komponen emosional), yaitu komponen yang berhubungan dengan rasa senang atau tidak senang terhadap objek sikap. Rasa senang merupakan hal yang positif, sedangkan rasa tidak senang merupakan hal yang negatif. Komponen ini menunjukkan arah sikap, yaitu positif dan negatif. Remaja peka terhadap keadaan disekitarnya, setelah banyak adegan kekerasan yang dilihat dan seringnya waktu yang dihabiskan di depan game online mempengaruhi respon remaja 
pada kejadian-kejadian disekitarnya. Remaja lebih memilih untuk menggunakan kekerasan dalam menyelesaikan masalah. Komponen konatif (komponen perilaku, atau action component), yaitu komponen yang berhubungan dengan kecenderungan bertindak terhadap objek sikap. Komponen ini menunjukkan besar kecilnya kecenderungan bertindak ata berperilaku seseorang terhadap objek sikap menurut Myers dan Gerungan (Walgito, 1999:111). Remaja yang sudah terlalu banyak terpengaruh dengan apa yang dilihat akan menunjukkan perubahan melalui sikap seperti ingin melukai dan menyakiti seseorang, bukan hanya lawan saja yang bisa dilukai namun teman pun bisa menjadi luapan amarahnya.

Berdasarkan kategorisasi adegan kekerasan dalam game online pada 100 responden, diketahui terdapat delapan orang yang mempunyai skor adegan dalam game online sangat rendah, delapan puluh tujuh orang yang mempunyai skor adegan kekerasan dalam game online tinggi, lima orang yang mempunyai skor adegan kekerasan dalam game online sangat tinggi.

Sedangkan pada kategorisasi agresifitas remaja pada 100 orang responden, diketahui terdapatdua belas orang yang mempunyai skor agresifitas rendah, delapan puluh lima orang yang mempunyai agresifitas tinggi, dan tiga orang yang mempunyai agresifitas sangat tinggi.

Menurut hasil perhitungan dengan menggunakan analisis korelasi product moment yang telah dibahs sebelumnya diketahui bahwa besarnya nilai korelasi antara adegan kekerasan dalam game online dengan agresifitas remaja sebesar 0,889. Ini berarti besarnya hubungan antara adegan kekersan damal game online dengan agresifitas remaja adalah sebesar $88,9 \%$. Artinya hubungan kedua variabel tersebut sangat kuat. Korelasi positif menunjukkan bahwa hubungan antara adegan kekerasan dalam game online terhadap agresifitas remaja searah. Artinya penggunaan game online yang semakin sering, maka tingkat agresifitas remaja akan tinggi.
Ada hubungan atau pengaruh yang terjadi antara adegan kekerasan dalam game online dengan agresifitas remaja juga diperkuat dengan hasilperhitungan analisis regresilinear sederhana, dimana dari hasil perhitungan tersebut nilai agresifitas sebesar 0,358, yang bernilai konstan.

Variabel adegan kekerasan dalam game online mempunyai pengaruh positif terhadap agresifitas remaja, dengan koefisien agresi sebesar 0,900 yang artinya apabila tingkat adegan kekerasan dalam game online tinggi maka tingkat agresifitas remaja akan menigkat 0,900 . Dengan adanya pengaruh positif ini, berarti bahwa antara variabel adegan kekerasan dalam game online dan agresifitas remaja menunjukkan hubungan yang searah. Jika variabel adegan kekerasan kekerasan dalam game online meningkat mengakibatkan agresifitas akan tinggi., begitu pula sebaliknya jika variabel adegan kekerasan semakin menurun mengakibatkan agresifitas remaja juga semakin menurun.

Dapat diketahui koefisien determinasi $\left(\mathrm{r}^{2}\right)$ sebesar 0,79. Dengan nilai koefisien determinan sebesar 0,79 menunjukkan bahwa variabel adegan kekerasan dalam game online sebesar $79 \%$ dan sisanya $21 \%$ dipengaruhi oleh variabel lain yang tidak termasuk dalam model, misalnya lingkungan, sekolah, keluarga, penggunaan media lain dan hubungan sosial.

Dengan nilai probabilitas $\mathrm{t}$ hitung yang sebesar 0,000 yang lebih kecil dari 0,005 menunjukkan bahwa variabel adegan kekerasan dalam game online mempunyai pengaruh yang dianggap sigifikan terhadap agresifitas remaja. Dengan demikian hipotesis yang diajukan diterima, atau adegan kekerasan dalam game online mempunyai pengaruh signifikan terhadap agresifitas remaja di Monster Game Center - Hasil penelitian ini menunjukkan bahwa teori S-O-R sebagai singkatan dari StimulusOrganism-Response terbukti. Dalam hal ini stimuli atau efek yang ditimbulkan karena bermain game online yang secara aktif pesan yang disampaikan berupa adegan-adegan kekerasan 
seperti membunuh, menembak, berkelahi menimbulkan perubahan sikap bagi para pemain game karena stimulus yang berlebihan.

Menurut Onong (1986:7) hal yang terpenting dalam komunikasi ialah bagaimana caranya agar suatu pesan yang disampaikan komunikator itu menimbulkan dampak atau efek tertentu pada komunikan.

Dampak yang ditimbulkan dapat diklasifikasikan menurut kadarnya, yaitu, dampak kognitif, dampak afektif, dampak behaviorial atau konatif

Khalayak, yakni pengguna di game center Monster, diasumsikan sebagai pelaku aktif yang sering menggunakan game online dan secara otomatis sering melihat adegan kekerasan. Khalayak dianggap dapat terpengaruh kehidupannya karena stimulus yang berlebihan. Media game online yang baru bila tidak diseleksi secara baik oleh pengguna dapat berdampak bagi para pengguna nya yaitu perubahan sikap dan perlu adanya pengawasan dari orang terdekat seperti orang tua. Game online dapat disebut sebagai media hiburan dan juga media sosial karena waktu bermain game pengguna juga dapat berhubungan dengan pengguna lain. Namun penggunaan game online yang berlebihan juga dapat memngganggu hubungan sosial para penggunanya. Karena pengguna tidak banyak bersosialisasi dengan dunia nyata dan justru apa yang dia lihat dalam game online secara terus menurus membuat nya terinspirasi untuk menirukan adegan-adegan yang ada dalam game online. Inilah yang akhirnya menunjukkan perubahan sikap pengguna.

Dari uraian diatas menunjukkan bahwa saat ini adegan kekerasan dalam game online di kalangan pengguna game center memberikan pengaruh bagi sikap mereka. Apalagi di umur pengguna yang rata-rata adalah remaja yang masih labil dan mudah menerima apa yang dia lihat. Untuk game online sebagai media komunikasi diharapkan untuk mendapatkan pengawasan dari pihak orang tua maupun pemerintah agar tidak berdampak buruk bagi remaja.

\section{Simpulan}

Berdasarkan hasil penelitian yang telah diuraikan pada bab sebelumnya dapat ditarik beberapa kesimpulan yaitu: Dalam penelitian ini menunjukan bahwa terdapat hubungan yang signifikan antara variabel Adegan Kekerasan dalam Game Online terhadap Agresifitas Remaja. Sedangkan besarnya hubungan kedua variabel tersebut adalah sebesar 0,889 atau 88,9\%. Hasil analisis korelasi menyebutkan bahwa hipotesis tersebut diterima karena nilai $\mathrm{r}$ signifikansi $\mathrm{p}<$ $0,05(0,000<0,05)$. Artinya terdapat hubungan positif dan signifikan antara adegan kekerasan dalam game online terhadap agresifitas remaja. Hasil analisis regresi menyebutkan bahwa hipotesis dapat diterima karena nilai t signifikan $\mathrm{p}<0,05(0,000<0,05)$ artinya, terdapat pengaruh adegan kekerasan dalam game online terhadap agresifitas remaja, dengan nilai $t$ hitung sebesar 19,199 maka terdapat hubungan yang positif pada agresifitas remaja. Analisis product moment pearson yang dilakukan untuk mengetahui presentase hubungan variabel adegan kekerasan dalam game online terhadap agresifitas remaja. Hasil analisis tersebut diperoleh koefisien determinan $\left(\mathrm{r}^{2}\right)$ sebesar 0,790 . Dengan nilai koefisien determinan sebesar 0,790 menunjukan bahwa variabel agresifitas remaja dipegaruhi oleh variabel adegan kekerasan dalam game online sebesar $79 \%$ dan sisanya $21 \%$ dipengaruhi oleh variabel lain yang tidak termasuk dalam model, misalnya lingkungan sekolah, keluarga, penggunaan media lain, dan hubungan sosial. Agresifitas remaja dinyatakan tinggi ditinjau dari tiga indikator yaitu kognisi, afeksi dan konasi. Masa remaja merupakan masa transisi, yaitu masa peralihan dari anak-anak menjadi dewasa. Pada masa inilah remaja mulai mengalami ketidakseimbangan emosi sehingga remaja mudah berubah, bergejolak, dan tidak menentu di mana remaja merasa kebingungan 
dalam mencari identitas dirinya. Penggunaan game online dinyatakan tinggi ditinjau dari tiga indikator yaitu frekuensi, perhatian, penerimaan berupa ketertarikan pengguna terhadap adegan kekerasan dalam game online. Seperti yang disebutkan dalam Teori S-O-R sebagai singkatan dari Stimulus-OrganismResponse, bahwa yang menjadi inti pokok adalah dalam proses perubahan sikap tampak bahwa sikap dapat berubah, hanya jika stimulus yang menerpa benar-benar melebihi semula.

\section{Daftar Pustaka}

Giandi, A. F., Mustikasari E, R. F., \& Suprapto A, H. (2012). Perilaku Komunikasi Pecandu Game Online Dengan Menggunakan Game Online. eJournal Mahasiswa Universitas Padjajaran Vol. 1 No. 1.

Koeswara, E, 1998, Agresi Manusia, PT Erasco, Bandung.

Sarwono, Jhonathan. 2006. Analisis Data Penelitian, Bandung: Alfabeta.

Walgito, Bimo, 2003, Psikologi Sosial, ANDI: Yogyakarta

http://www.ketok.com/ 